Original Article

\title{
Nursing process as a strategy in the development of competence for self-care*
}

\author{
Processo de enfermagem como estratégia no desenvolvimento de competência para o autocuidado \\ Elproceso de enfermería como estrategia en el desarrollo de la competencia para el autocuidado
}

\author{
Cynthia de Freitas Sampaio ${ }^{1}$, Maria Vilani Cavalcante Guedes ${ }^{2}$
}

\begin{abstract}
Objective: To investigate the contribution of clinical care and education of nursing in a hospital context, in the development of competence for self-care for people with chronic renal failure. Methods: A case study conducted with a patient during hospitalization in Fortaleza, through the nursing process proposed by Orem determining deficiencies and enabling self-care demands satisfaction from him. Results: The requisites of therapeutic self-care demands of health deviation sef-care requisites enabled the identification of three nursing diagnoses based on the North American Nursing Diagnosis Association - NANDA for which interventions were defined based on NIC and results according to NOC. Conclusion: In the hospital context, clinical and educational nursing care based on the nursing process proposed by Orem contributes as a facilitator for the development of competence for self-care in people with chronic disease.
\end{abstract}

Keywords: Hypertension; Diabetes mellitus; Renal insufficiency, chronic; Nursing process; Self care

\section{RESUMO}

Objetivo: Investigar a contribuição dos cuidados clínicos e educativos de enfermagem em um contexto hospitalar, no desenvolvimento de competência para o autocuidado em pessoa com insuficiência renal crônica. Métodos: Estudo de caso realizado com paciente durante período de internação hospitalar em Fortaleza-CE, mediante o processo de enfermagem proposto por Orem que determina as deficiências e exigências de autocuidado possibilitando a satisfação das mesmas. Resultados: Os requisitos de demanda terapêutica de autocuidado no desvio de saúde possibilitaram a identificação de três diagnósticos de enfermagem fundamentados na North American Nursing Diagnosis Association - NANDA para os quais se definiram intervenções com base na NIC e resultados obtidos de acordo com a NOC. Conclusão: No contexto hospitalar, o cuidado clínico e educativo de enfermagem fundamentado no processo de enfermagem proposto por Orem contribui como facilitador para o desenvolvimento de competência para o autocuidado em pessoa com adoecimento crônico.

Descritores: Hipertensão; Diabetes mellitus; Insuficiência renal crônica; Processos de enfermagem; Autocuidado

\section{RESUMEN}

Objetivo: Investigar la contribución de los cuidados clínicos y educativos de enfermería en un contexto hospitalario, en el desarrollo de la competencia para el autocuidado en persona con insuficiencia renal crónica. Métodos: Se trata de un estudio de caso realizado con el paciente durante el período de internamiento hospitalario en Fortaleza-CE, mediante el proceso de enfermería propuesto por Orem que determina las deficiencias y exigencias de autocuidado posibilitando la satisfacción de las mismas. Resultados: Los requisitos de demanda terapéutica de autocuidado en la alteración de la salud permitieron la identificación de tres diagnósticos de enfermería fundamentados en la North American Nursing Diagnosis Association - NANDA para los cuales se definieron intervenciones con base en el NIC y resultados obtenidos de acuerdo con el NOC. Conclusión: Se recomienda la implementación de habilidades de autocuidado en individuos con padecimiento crónico como estrategia permanente y continua. Como instrumento metodológico, el proceso de enfermería permite a la enfermería el desarrollo de actividades clínico-educativas que, juntamente con el paciente, fomentan la competencia para el autocuidado.

Descriptores: Hipertensión; Diabetes mellitus; Insuficiencia renal crónica; Procesos de enfermería; Autocuidado

\footnotetext{
* Study conducted at the General Hospital of Fortaleza - Fortaleza (CE), Brazil.

${ }^{1}$ Masters in Clinical Care in Nursing and Health, State University of Ceará - UECE - Fortaleza (CE), Brazil.

${ }^{2}$ Professor of the Graduate Program in Clinical Care in Nursing and Health, State University of Ceará - UECE - Fortaleza (CE), Brazil.
} 


\section{INTRODUCTION}

People affected by chronic health conditions require significant adjustments and changes in lifestyle aimed at improving their condition. The World Health Organization (WHO) recommends education focused on self-care as an instrument for the development of competences and abilities of their health care to support learning in order to live more comfortably with chronic diseases ${ }^{(1)}$.

As non-communicable chronic health conditions, systemic arterial hypertension (SAH) and diabetes mellitus (DM) are worth mentioning given their high incidence, prevalence, mortality and degree of impairment of its complications. Considered a highly prevalent condition in our field, SAH affects over $30 \%$ of the population, besides being responsible for triggering major complications of varying degrees of disability or death ${ }^{(2)}$. DM, on the other hand, has stood out given its visible increase in recent decades, the incidence and prevalence in worldwide scale ${ }^{(3)}$. In Brazil, there is an estimation that $11.0 \%$ of adults aged over 40 years are affected by this comorbidity, which means about five and a half million people with the disease ${ }^{(4)}$.

Both SAH and DM are among the diseases that may trigger impairment in kidney structures, leading to the development of chronic renal failure (CRF). However, DM has been assigned as its main cause, the CRF is the complication that affects about $40 \%$ of patients with the disease ${ }^{(4)}$. Therefore, this desease is configurated as a complication responsible for injuries that generates social and personal impacts on the lives of affected people. So this situation requires clinical care and educational interventions throughout the course of the disease.

From this perspective, the development of selfcare skills for these individuals is recommended as permanent and continuous. The nursing profession being a supporter and facilitator, implements strategies for health promotion and education that assist the person in the redefinition of their health condition, promoting self-care practices to be worked on in search of a better life.

For Orem, self-care is the practice of the activities performed by the individual for their own benefit, in order to maintain life, health and well-being ${ }^{(5)}$. In this sense, Orem has developed a nursing theory, Self-Care Deficit Nursing Theory, consisting of a general theory composed of three interrelated theories: the theory of self-care, the self-care deficit theory and theory of nursing systems.

Designed by the professional, the nursing system is based on self-care demands and the person's ability to perform these activities. Thus, to satisfy the requirements of the individual's self-care (universal developmental and health deviation), the theorist has identified three classifications of nursing systems: wholly compensatory system, partly compensatory system and supportive-educative system ${ }^{(5)}$.

Orem comprises the nursing process as a method of determining self-care deficiencies that allows the definition of the roles of nurses and the self-care agent, so as to satisfy the self-care requisites. Thus, as the theorist proposes the nursing process should be worked out in three steps. The first is represented by the phase of assessment diagnosis and prescription, that determines whether or not there is a need for nursing care, while the second step comprises the planning phase of the nursing systems and performance of their actions, which should primarily enable people to become a true agent of self-care. The third and final step, corresponds to the production and implementation of the nursing system, when the nurse assists the individual as their needs for self-care in order to achieve health outcomes identified and described. In the last step of the nursing process, control of assisting actions, there is an evaluation of the effectiveness of regulatory operations when nurse and patient together evaluate the effectiveness and promote changes in the proposed process ${ }^{(5)}$.

In this perspective, given the problem of chronic diseases and the possibility of contribution proposed by the methodology of care to patients and professionals, which encourages the provision of quality care focused on the health needs of individuals, the question is: which clinical and educational care does the nurse perform during hospitalization for patients with chronic diseases from the perspective of developing competencies for self-care?

In seeking to address this issue, this study aimed to investigate the contribution of clinical and educational care of nursing in a hospital context, for the development of competence for self-care for people with chronic renal failure related to SAH and DM.

\section{METHODS}

This is a quatitative approach study, descriptive, elaborated based on the model of clinical case study. The applicability of the case study is appropriate in nursing care because they enable the performance of a thorough study of the problems and needs of the individual, family or community and fosters the development of strategies to solve or reverse the problems found ${ }^{(6)}$.

This research was conducted during the month of November of 2011 in a nephrology hospitalization unit with 20 beds at the General Hospital of For- 
taleza, a reference hospital in general care belonging to the tertiary level of public health in the city of Fortaleza-CE .

The case was chosen for accessibility and interested researchers for being a newly admitted patient with chronic renal failure in dialysis who presented inability with therapeutic regimens and poor knowledge about care measures to be taken on his behalf.

During the institutionalization of this patient, one of the researchers applied the nursing process based on the Nursing Systems Theory of Dorothea Orem in seven sequential encounters, during an interval of 3 weeks, with an average duration of 120 minutes, keeping in mind the self-care needs perceived and patient's ability to perform them.

From this perspective, the nursing process was working, as the three steps discussed by Orem: $1^{\text {st }}$ step - data collection was held through interviews that supported the identification and assessment of nursing diagnoses, with subsequent prescribing interventions; $2^{\text {nd }}$ step - planning actions by the nursing system, with prioritization of actions which can enable the patient to become self-care agent; $3^{\text {rd }}$ step - implementation and evaluation of nursing actions in the proposed system ${ }^{(5)}$.

In order to collect data relating to the health history and lifestyle habits of this client, aiming to get information to support the identification of nursing phenomena, we used a structured interview script based on Orem `s theory. This script enabled the collection of data through interviews, physical examination and medical record chart consultation.

Clinical judgment of the collected data, as well as the defining characteristics and related factors determined by the classification of the North American Nursing Diagnosis Association NANDA-enabled identification of nursing diagnoses that helped the researchers to trace goals and prescribe the appropriate nursing interventions to achieve the mentioned goals.

When applied to clinical nursing care, the nursing classifications revealed themselves as effective tools to point solutions, unify conducts and ensure effective results to meet our client's needs. It is evident, then, as a way for the design professional identity, contributing to autonomy in care ${ }^{(7)}$. In this perspective, in order to strengthen practice, standardizing the language in nursing, we used the systems classification of Nursing Diagnoses (NANDA-I), the Nursing Interventions Classification (NIC) and Nursing Outcomes Classification (NOC), which showed dynamic interaction during the implementation of the nursing process and at the same time facilitated the detection of essential care and organization of nursing actions in order to meet the health needs of the individual receiving care.
Further, the care plan was performed, which was based on the Orem 's theory of nursing systems. Therefore, nursing actions guided by clinical and educational care are prioritized, and in the perspective for developing competencies for self care. At the end, after the implementation of the care plan proposed, together with the client, we proceeded to the evaluation of suggested nursing actions, guided by the supportive-educative nursing system, which proved to be consistent with the clinical reality of patient care with CRF, chronic complication which comes from hypertensive state and metabolic disorder.

In accordance with Resolution 196/1996 of the National Health Council/Ministry of Health ${ }^{(8)}$, the ethical and legal issues related to research with human beings were considered and respected during the entire research. Thus, the client was duly informed about the purposes of the study, ensuring him concerning the anonymity and freedom of participation. His approval was obtained throught his signature on the Consent Form before the start of data collection, after being informed about the purpose of our goal. The study was approved by the Research Ethics Committee (REC) of the State University of Ceara with Protocol No. 10244361-0 and by the institution REC study setting with Protocol 070.716/10.

\section{RESULTS}

\section{Case presentation}

HGS, 48 year old, male, married, Catholic, born in Fortaleza, CE. High school complete, unemployed for a year, family income of a minimum wage. Type II DM for 10 years, SAH and CRF not on dialysis for 1 year. In use of oral antihypertensive and insulin therapy. In October 2010, he was admitted to the emergency room of that hospital with hypertension, evolving with diagnosis of hypertension and CRF. On October 17th, 2011, he returned to the emergency room with complaints of headache, vomiting and edema in lower limbs, starting hemodialysis (HD) by catheter in the right jugular. Refers to hypertensive and diabetic mother who died because of cardiovascular complications and two brothers with DM. Made changes in eating habits after the diagnosis of DM and SAH with adoption of a low sodium diet, low-fat, using diet sweetener and abolished alcohol consumption. Had poor prior knowledge on SAH and DM. Demonstrated inability to therapy instituted, poor knowledge about the current health status and care measures to be developed for his own benefit, but shows willingness and interest in learning more about comorbidities and solving doubts. Physical examination: preserved cognitive function, communicative, deambulante with 
slow walking, spontaneous breathing without oxygen support, hemodynamically stable $(B P=120 / 80 \mathrm{mmHg}$, $\mathrm{HR}=82 \mathrm{bpm})$, afebrile $\left(\mathrm{T}=36.4^{\circ} \mathrm{C}\right)$ eupneic $(\mathrm{RR}=18$ $\mathrm{rpm})$, hyperglycemic $(\mathrm{BG}=240 \mathrm{mg} / \mathrm{dL})$, pale, fair skin and decreased skin turgor. Oral diet and medication therapy with good acceptance. Normocephalic, scalp intact, symmetrical face, eyes aligned, spontaneous eye opening, isochoric pupils, ocular mucosa hypochromic, eyesight and hearing preserved. Biological dressing intact in HD catheter positioned in the right jugular. Thorax symmetric breath sounds in both physiological hemithorax. Normal heart sounds in two stages. Flaccid abdomen, noise-fluid-present. Oliguric, with regular bowel habit. Edema in lower limbs with positive signal locker $(+++/ 4+)$, presence of calluses. Thready dorsal pedal pulse, decreased peripheral perfusion. Sleep and rest preserved. Anthropometric data: weight: $69 \mathrm{~kg}$, height: $1.75 \mathrm{~m}$; BMI: $22.53 \mathrm{~kg} / \mathrm{m}^{2}$, WHR: 0.94, AC: 89cm.

\section{Therapeutic Self-care Demands requisites:} foundation for clinical judgment, decision making and planning of nursing care

After the collecting data, were gathered specific information in order to identify requisites for therapeutic self-care demands in health deviation. The requisites are set out in Table 1 data for better viewing.
Table 1. Health deviation self-care requisites of the participant. Fortaleza/CE, 2011

\begin{tabular}{l}
\hline Health deviation self-care requisites of the participant \\
To be aware of the effects and outcomes of conditions and \\
disease states \\
To learn how to live with the treatment measures in lifestyle \\
To learn how to live with the effects of pathological conditions \\
Low fluid intake \\
To have a diet with restriction of sodium, carbohydrates, proteins \\
and foods with high amount of potassium \\
To effectively perform prescribed therapeutic measures \\
To recognize the need for specific forms of health care service \\
\hline
\end{tabular}

The requisites of therapeutic self-care demand favored the clinical evaluation and diagnostic reasoning and thus allowed the identification of three nursing diagnoses (ND). These belong to three of the thirteen fields of taxonomy II of NANDAI: nutrition (excessive fluid volume related to compromised regulatory mechanisms); perception/ cognition (poor knowledge related to unfamiliarity with information resources); life principles (decision conflict related to lack of relevant information). Based on these, goals were drew in order to meet the requisites of therapeutic self-care demand and methods to achieve them.

As the ND form the basis for selecting nursing interventions to achieve the results of responsibility of the nurse ${ }^{(9)}$, after identifying these as well as the goals and methods, we proceeded to the selection of nursing interventions favoring the achievement of goals, as shown by the data in Table 2.

Table 2. Nursing diagnoses, goals, methods and interventions based on health needs identified through the Health deviation selfcare requisites of the participant investigated. Fortaleza / CE, 2011

\begin{tabular}{|l|l|l|l|}
\hline Nursing Diagnoses & Goals & Methods & Intervations \\
\hline $\begin{array}{l}\text { Poor knowledge related } \\
\text { to unfamiliarity with } \\
\text { information resources } \\
\begin{array}{l}\text { Decision conflict related } \\
\text { to the lack of relevant } \\
\text { information }\end{array}\end{array}$ & $\begin{array}{l}\text { Kaving knowledge about the disease and measures of care to } \\
\text { prevent complications and re-hospitalization } \\
\text { Recognizing the need to implement appropriate care of their } \\
\text { own health for quality of life }\end{array}$ & $\begin{array}{l}\text { Teaching } \\
\text { Providing } \\
\text { favorable dialogue } \\
\text { doubts and wishes }\end{array}$ & $\begin{array}{l}\text { Teaching: disease } \\
\text { process } \\
\text { Teaching: prescription } \\
\text { drugs } \\
\text { diet }\end{array}$ \\
\hline $\begin{array}{l}\text { Excessive fluid } \\
\text { volume related to } \\
\text { regulatory compromised } \\
\text { mechanisms }\end{array}$ & $\begin{array}{l}\text { To follow proposed diet to CRF condition } \\
\text { Being able to control their fluid intake } \\
\text { Understanding the need and importance of HD sessions }\end{array}$ & Teaching & $\begin{array}{l}\text { Control of nutrition } \\
\text { Fluid control } \\
\text { Hemodialysis therapy }\end{array}$ \\
\hline
\end{tabular}

For each nursing diagnosis identified in NANDA-I, interventions have been proposed and activities implemented based on the NIC. The data in Table 3 shows the actions performed in each of the proposed interventions to achieve the goals of nursing diagnoses identified and the results obtained, as standardized by the NOC. 
Table 3. Nursing diagnoses, interventions, activities implemented and results achieved based on the health needs identified through the Health deviation self-care requisites of the participant investigated. Fortaleza/CE, 2011

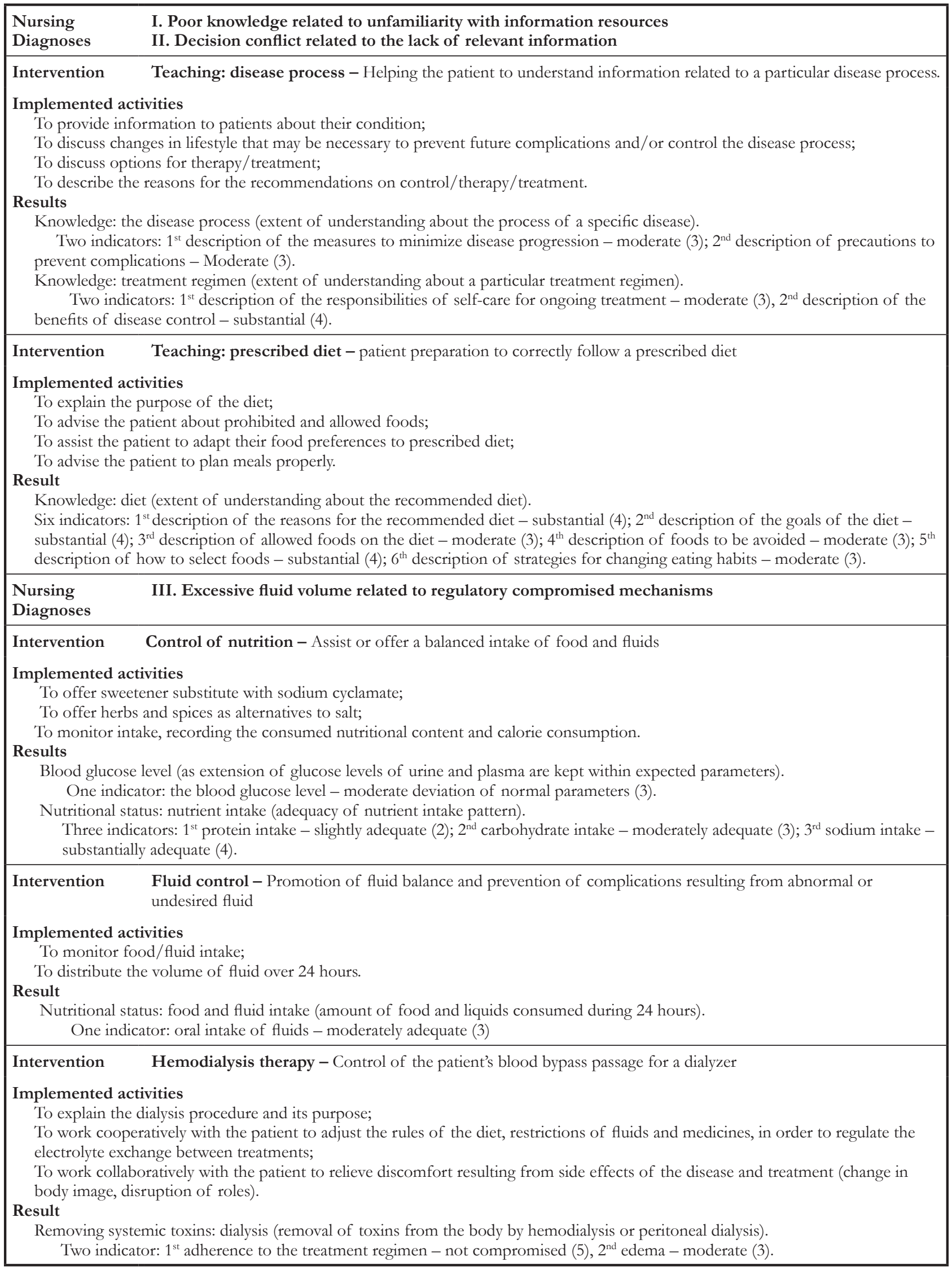




\section{DISCUSSION}

The health deviation of self-care requisites showed strong relationship with the CRF, disease condition that causes changes in physiological and biopsychosocial patient state, requiring changes in attitude and behavior, proposing the adoption of a more healthy way of living.

According to the $\mathrm{WHO}$, to control and prevent chronic conditions adherence is essential to long-term treatments and prepare to self-manage a chronic condition $^{(1)}$. The domain knowledge is closely related to the predisposition of the individual to take on the self-care by encouraging stress reduction associated with the disease, improving self-esteem, social acceptance and greater responsiveness to treatment ${ }^{(10,11)}$.

Thus, adequate knowledge about the disease is a prerequisite for self-care, we sought to implement it through the intervention teaching: disease process from the perspective of a more collaborative approach that encouraged the individual to take responsibility and control of their health condition and life.

Therefore, the effective nursing intervention was based on health education, providing patients with information on their health condition. For this purpose appropriate changes in lifestyle were discussed in expectation of controlling the disease process and at the same time, explained what the options of therapy/treatment available and the reasons for the recommendations on control/therapy/treatment. These implemented actions were guided in the perspective, as education activities for self-care in DM should include key information, to assist the individual to acquire skills to control the disease, promoting a healthy lifestyle ${ }^{(12)}$.

Thereby, this intervention has obtained progressively satisfactory response during the encounters. In the third encounter, the patient showed understanding of the possible complications of SAH and CRF could have been avoided if he had been more cautious in his choices and had given more importance to the initial diagnosis of DM. Now it was time to admit the diagnosis of CRF and take the necessary steps to live with the disease, which required routine HD sessions.

The final result of the activities demonstrated the acquisition of knowledge about the disease process installed, thus, minimized the distress of the patient. Therefore, helped him understand his chronic condition that requires long and continuous treatment without the possibility of cure and requires motivation and discipline to implement necessary changes in daily lifestyle.

As evidenced, the pursuance of dietary prescription is one of these essential changes in patients with CRF. Therefore, it constitutes a strong ally in the management of the disease itself as well as in the control of SAH and DM. This is because, in renal, metabolic and blood pressure control should be strengthened both in terms of drug therapy as the non-drug ${ }^{(4)}$. In this view, education for self-care should include the restriction of dietary counseling with diverse sources of sodium, carbohydrates, proteins and foods with lots of potassium, with a focus on individualization, always according to the sociocultural dietary habits of the individual.

It is known that diabetic nephropathy (DN) is the leading cause of chronic renal failure in patients undergoing hemodialysis (HD), it is suggested that in those with DM, the protein restriction is capable of slowing the progression of $\mathrm{ND}^{(4)}$. Consistent with the literature, one must participate in the monitoring of disease through conscious choice of healthier foods, the number of meals and amount of food, so that the self-care strategy is permanent and continuous ${ }^{(4)}$.

Thus, in order to prepare the patient to pursue the prescribed diet, assisting in the performance of a balanced food intake, the following nursing interventions were implemented: education, adequate diet and nutrition control. Such activities included guidance on the nutritional needs of food to be eaten and avoided. In this sense, the patient was encouraged to use a diet sweetener without sodium cyclamate as well as herbs and spices instead of sugar and salt, respectively, as well as helped him planning more appropriately fractionated meals, adapting prescribed diet to his food preferences, monitoring intake and nutritional content.

The implementation of these activities showed relative difficulty, because the patient was resistant to diet restricted in carbohydrates, such as rice, pasta and manioc flour and also protein, especially red meat and fat that, according to the regional culture, these foods give a sense of satiety.

Accordingly, the patient was guided about the food groups and the need to adjust the intake of carbohydrates and proteins. In subsequent encounters, it was reported that he was prioritizing the consumption of vegetables and consuming only two sources of carbohydrates in the main meal. The reduction of protein intake was more difficult, because of the food preferences and for being "what gave flavor to the food."

The suggestion to use spices and herbs to promote appetite was readily embraced intervention by the patient, in the second week, he reported having shared the information with his wife, requesting her to arrange them at home. In hospital, we negotiated with the instution the addition of lemon and oregano to his meals.

It was observed, as a result of these interventions, the greater possibility of adaptation in sodium intake, protein and carbohydrates in daily consumption. Thus, it was possible to assist him in moderate control of blood glucose levels and blood pressure. However, the reduction in consumption of protein was shown to 
be the most difficult, because the patient was used to consuming plenty of this food group.

Due to the fact that fluid restriction is an indispensable component to control of the CRF, we sought to promote self-care for the fluid balance via implementation of fluid control intervention, in order to train and guide the patient to monitor his fluid intake, distributing the allowed liquid volume throughout the day. It obtained therefore moderately adequate result.

In CRF, dialysis becomes necessary when the drug therapy, diet and fluid restriction become insufficient. In this clients, the HD is the most commonly performed type of dialysis ${ }^{(13)}$. Thus, before the need of this therapy in clinical reality of patients, it was implemented the intervention therapy for hemodialysis. The dialysis procedure and its purpose were explained to them, working cooperatively to adapt the rules of the diet restrictions of liquids and medications in order to regulate the electrolyte between treatments. Furthermore, we sought to relieve discomfort resulting from side effects of the disease and treatment (change in body image, disruption of roles). As noted, these activities facilitated adherence to the therapeutic regimen, with reduction of edema in lower limbs.

Thus, as evidenced, the proposed actions were based on supportive-educative nursing system proposed by Orem, in order to guide the client to perform self-care measures.

Given the above, it was possible to state that the patient's responses to interventions performed were positive. Its evolution was satisfactory because of the efficacy of the interventions implemented, as well as personal motivation and the willingness of the patient to acquire significant knowledge able to assist him in deep in knowledge of the comorbidities and self-care measures to be developed.

In studies of individuals with CRF and DM, the application of the nursing process based on Orem's
Theory of Self Care and the development of educational self-care also obtained significant results, contributing to the achievement of the highest level of independence possible and impacting patient on their health status ${ }^{(12,13)}$.

Therefore, we recommend the implementation of self-care skills in individuals with chronic disease such as permanent and continuous strategy. As a methodological tool, the nursing process provides the development of nursing clinical and educational activities which, together with the patient, foster competence for self-care.

During this research, the nursing team of the unit sought to engage in planned activities when possible. However, the technical and managerial needs represented barriers. Thus, the limitations of this study are associated with the method of single case study and poor team involvement given the planned actions.

However, the results showed the importance of adopting the nursing process as a strategy in the development of competence for self-care, foreseeing the development of more related studies.

\section{CONCLUSION}

In the hospital context, clinical and educational care in nursing based on nursing process proposed by Orem contributes as a facilitator for the development of competence for self-care in people with chronic disease.

The supportive-educative nursing system provides the person with chronic renal failure enhancement skills with their health care benefiting of nursing care as a facilitator resource. This strategy requires an invitation to the subject to take control of their health condition and living as responsible for their choices and co-participant in the process of keeping healthy. This way one may avoid complications of the disease which may generate disability or death.

\section{REFERENCES}

1. Organização Mundial da Saúde. Cuidados inovadores para condições crônicas: componentes estruturais de ação: relatório mundial. Brasília (DF): Organização Mundial da Saúde; 2003.

2. VI Diretrizes Brasileiras de Hipertensão Arterial. Rev Bras Hipertens. 2010; 17(1):1-64.

3. International Diabetes Federation. Complicações do diabetes e educação. Diabetes Clínica. 2002; 6(3):217-20.

4. Sociedade Brasileira de Diabetes. Diretrizes da Sociedade Brasileira de Diabetes 2009. Itapevi (SP): A. Araújo Silva Farmacêutica; 2009.

5. Orem DE. Nursing: concepts of practice. 4th ed. St. Louis: Mosby; 1991.

6. Galdeano LE, Rossi LA, Zago MM. [Instructional script for the elaboration of a clinical case study]. Rev Latinoam Enferm. 2003; 11(3): 371-5. Portuguese.

7. Sampaio RS, Santos I, Amantéa ML, Nunes AS. [The nursing Interventions classification in the clinical practice of Brazilian nurses. Acta Paul Enferm. 2011; 24(1):120-6.

8. Brasil. Ministério da Saúde. Conselho Nacional de Saúde. Resolução n. 196, de 10 de outubro de 1996. Diretrizes e normas regulamentadoras de pesquisas envolvendo seres humanos. Bioética. 1996; 4(2 Supl): 15-25.

9. North American Nursing Diagnosis Association International. Diagnósticos de enfermagem da NANDA: definições e classificação, 2009-2011. Porto Alegre: Artmed; 2010. 
10. Sousa VD, Zauszniewski JA. Toward a theory of diabetes self-care management. J Theory Constr Test. 2005; 9(2):61-7.

11. Steed L, Cooke D, Newman S. A systematic review of psychosocial outcomes following education, selfmanagement and psychosocial interventions in diabetes mellitus. Patient Educ Couns. 2003; 51(1):5-15.
12. Torres HC, Souza ER, Lima MH, Bodstein RC. Educational intervention for self-care of individuals with diabetes mellitus. Acta Paul Enferm. 2011; 24(4):514-9.

13. Ramos IC, Chagas NR, Freitas MC, Monteiro AR, Leite AC. A teoria de Orem e o cuidado a paciente renal crônico. Rev Enferm UERJ. 2007; 15(3):444-9. 